Research Article

\title{
Removal of Zinc from Aqueous Solution Using Activated Oil Shale
}

\author{
Ehssan Nassef $\mathbb{D D}^{1}$ and Yehia Eltaweel ${ }^{2}$ \\ ${ }^{1}$ Petrochemical Engineering Department, Faculty of Engineering, Pharos University, Alexandria-21311, Egypt \\ ${ }^{2}$ Chemical Engineering Department, Faculty of Engineering, Alexandria University, Alexandria, Egypt \\ Correspondence should be addressed to Ehssan Nassef; ehssan.nassef@pua.edu.eg
}

Received 7 February 2019; Revised 17 June 2019; Accepted 4 August 2019; Published 25 August 2019

Academic Editor: Shayessteh Dadfarnia

Copyright (C) 2019 Ehssan Nassef and Yehia Eltaweel. This is an open access article distributed under the Creative Commons Attribution License, which permits unrestricted use, distribution, and reproduction in any medium, provided the original work is properly cited.

\begin{abstract}
Egyptian oil shale was investigated as a source of adsorbent for removal of zinc from aqueous solutions. Egyptian oil shale (OS) was used as an adsorbent without any treatment, then thermally activated in absence of air (Carbo-OS), and separately burned to produce ash (OS-ash). Egyptian oil shale was also chemically activated by zinc chloride $\left(\mathrm{ZnCl}_{2}-\mathrm{OS}\right)$ respectively. The present study aims at investigating the removal of $\mathrm{Zn}^{2+}$ ions from an aqueous solution via adsorption and thermal and chemical activation of locally sourced oil shale. Also, the effect of different operation parameters, like heavy metal and sorbent concentration as well as adsorbent's uptake time of heavy metals is studied. It was found that activated oil shale successfully removed high amount of $\mathrm{Zn}$ from an aqueous solution. As the adsorbent concentration was increased keeping zinc concentration constant, greater metal removal from the solution was observed. And, as the zinc concentration was increased keeping sorbent concentration constant, higher metal loading per unit weight of the sorbent was achieved. The Langmuir isotherm model fit the experimental data of $\mathrm{Zn}^{2+}$ ions. The results indicated that oil shale could be used to adsorb $\mathrm{Zn}^{2+}$ ions and that thermally activated oil shale resulted in $99 \%$ removal for $\mathrm{Zn}^{2+}$.
\end{abstract}

\section{Introduction}

Toxicities in water due to heavy metal pollution play a crucial role in determining its effects on all living organisms living in water as well as land, including humans. Industries dealing with processing of metals, plating, etc., are a major source for generation of these heavy metal toxins. The high costs of ingredients and treatment of water resources create the major problems in the developing countries that suffer from water pollution. The adsorption process provides an attractive alternative treatment, especially if the adsorbent is inexpensive and readily available. Activated carbon is the most common material used for retrieving pollutants such as coloring matters from potable water or pretreated wastewater. It is however an expensive material due to its high costs of manufacturing and regeneration. To substitute activated carbon, some studies have been done on natural materials or agricultural and industrial wastes.
For this purpose, the present work concerns the elaboration of a cost-effective substitute for commercial adsorbents currently used for water treatment by using the Egyptian oil shale rocks from Al-Quseir area as a source of adsorbent material. Oil shale consists of marlstone-type sedimentary inorganic material containing complex organic polymers with high molecular weight. The organic kerogen is a three-dimensional polymer, insoluble in conventional organic solvents, and associated with small amounts of benzene-soluble organic material bitumen [1-5]. There are few heavy metals that gets eliminated though the natural mechanism of the body; however, few heavy metal ions remain accumulated in the cells and tissues like that of zinc, lead, etc. Thus, such accumulation can lead to many chronic health issues in the organism's body. As these heavy metals are of high specific density, it can be highly toxic at even low concentrations if not exposed within the permissible limit. For example, prolonged exposure to zinc dust that is released 
from industries can lead to nervous damage. Using oil shale was dictated firstly, by the composition of this oil shale which contains both organic matter (a good precursor of activated carbon) and clays (known by their adsorption properties) [1]. Secondly, the previous researches showed that the adsorbent elaborated from oil shale by thermal processing or chemical activation possessed good capacities to remove some organic substances and heavy metals.

Activated carbons were usually prepared by heating precursors at higher temperatures followed by activation either physically or chemically. An important advantage of the chemical activation is that the process normally takes place at a lower temperature and shorter time than those used in physical activation. Activated carbons were usually prepared by heating precursors at higher temperatures followed by activation either physically or chemically. An important advantage of the chemical activation is that the process normally takes place at a lower temperature and shorter time than those used in physical activation [6]. Moreover, the carbon yield in chemical activation is usually higher than in physical activation, because the chemical agents are substances with dehydrogenation properties that inhibit the formation of tar and reduce the production of other volatile products [7]. Shawabkeh [8] investigated carboaluminosilicate materials prepared from Jordanian oil shale by activation with $95 \mathrm{wt} . \%$ sulfuric acid and $5 \mathrm{wt} . \%$ nitric acid. Al-Asheh et al. [9] studied sorption of the organic pollutant 4-nitrophenol (4-NP) by physically and chemically activated Jordanian oil shale. Physical activation was carried out by treating the pyrolyzed oil shale with $\mathrm{CO}_{2}$ at $830^{\circ} \mathrm{C}$, while chemical activation was achieved by using $\mathrm{KOH}$ and $\mathrm{ZnCl}_{2}$ as impregnating agents. Ichcho et al. [10] recorded experiments undertaken to determine the suitable conditions for the use of Moroccan oil shale of Timahdit, as an adsorbent for water treatment. The preparation has been carried out by carbonization after impregnation of the oil shale with phosphoric acid. New activated adsorbents for radionuclides have been prepared by Khouya et al. [11] from Moroccan oil shales by pyrolysis of the natural material at $550^{\circ} \mathrm{C}$ flowed by a $\mathrm{KMnO}_{4}$ activation. It is not just living organisms, but these heavy metal ions can accumulate in the environment, i.e., land, water, and air, and pollute it. Among all the heavy metals, $\mathrm{Zn}$ ions are believed to be the most toxic and intense polluters, even at very low concentrations. To overcome this issue, novel approaches need to be devised for reducing the harmful effects of heavy metal pollution and checking them within their permissible limits set against various water bodies. Some of the common approaches implemented are ion exchange, heavy metal precipitation, coagulation, complexation, evaporation, reverse osmosis, electrolysis, etc. Heavy metal precipitation is used for removing traces of heavy metals from wastewater, whereas coagulation involves interaction between inorganic coagulant and the pollutants for its elimination. The bioadsorption process using low-cost bioadsorbents is considered as the most feasible decontamination method, which is also known for being simple and permitting regeneration of toxic metallic sludge. Scaling up of this technology into a pilot study or industrial level can be a crucial step to analyze the applicability of this technology from one side and to test its sustainability from the other side [12]. The complexation method involves complex formation of the heavy metal ions with a chemical complexing agent for its removal. The evaporation of the process involves heat treatment for heavy metal removal. In case of reverse osmosis, a dense barrier is used where most of the separation of heavy metal occurs. Ion-exchange process is the widely used one that involves adsorbents, such as activated carbon and ion-exchange resins, for removal of trace metals ions from water bodies. Though an effective method, the use of activated carbon and ion-exchange resins have been found to be costlier in terms of regeneration as well as procurement. AlQodah et al. [13] studied the adsorption characteristics of a pesticide in aqueous solutions using acid-treated oil shale ash in a series of batch adsorption experiments. Shawabkeh et al. [14] used Jordanian acid treated oil shale ash as an adsorbent for the removal of copper and zinc from aqueous solution. Thus, researchers have moved towards using more cost-effective materials like that of carbonaceous materials, which have been obtained from slurry waste of the fertilizer plants. This adsorbent is used for the removal of $\mathrm{Cu}^{2+}, \mathrm{Ni}^{2+}$, $\mathrm{Co}^{2+}$, and $\mathrm{Zn}^{2+}$ ions that fits well in the Langmuir isotherm. Al-Asheh and Banat used Jordanian oil shale in adsorption of copper and zinc ions from aqueous solutions [9]. Pimentel et al. utilized the oil shale waste material, and spent shale without any treatment was utilized as an adsorbent for $\mathrm{Cu}$ (II) removal from aqueous solution [15].

Therefore, the objective of the present work was to explore the effect of physical and various chemical activation methods on adsorption efficiency of oil shale rocks and compare the results with the results obtained from using oil shale without any treatment. To explore the adsorption efficiency, zinc ions were chosen in this study because of its known strong adsorption onto solids and its recognized usefulness in characterizing adsorptive material [14-16].

Since the last two decades, biological origin materials, also known as biosorbents, have evolved for removal of such toxic heavy metals. These adsorbents might contain algae, bacteria, and fungi. This category of absorbent consists of physical properties of carbohydrates, proteins, and lignins along with their functional groups that act as scavengers of toxic heavy metal ions. This is much preferred because of the high recovery rate, better performance, cost-effectiveness, simple pretreatment process, and high availability as compared to abovementioned adsorbents. These natural materials of the biological origin possess metal sequestering characteristics that are involved in reducing the heavy metal concentration in aqueous solution from ppm to ppb level [17].

Recently, researchers have focused on use of oil shale as the adsorbent material in removing the toxic heavy metals from the aqueous solution. It consists of $10-50 \%$ saprogenictype organic matter (mainly algae). Oil shale is the sedimentary rock which is a mix of minerals and constitutes both solid as well as organic matter that are combustible, such as kerogen and bitumen, therefore making it a source of obtaining fossil fuel. In addition to this, its high availability and low cost leads to its consideration as an effective 
absorbent material, and this had the ability to regenerate or restore after removal of heavy metal ions like Fe, $\mathrm{Zn}, \mathrm{Ni}, \mathrm{Co}$, $\mathrm{Hg}, \mathrm{Pb}$, and $\mathrm{Cu}$. The quality of the shale oil depends upon the thermal treatment temperature for obtaining the shale oil, mass ratio of adsorbent, and solution temperature. Also, byproducts obtained from oil shale processing can be used as effective adsorbents like that of oil shale ash, which is highly capable of removing heavy metal ions like cadmium and lead [18-21].

Hence, the present study focused on the locally available oil shale that was used in removing the heavy metal ions like that of $\mathrm{Zn}^{+2}$ from the aqueous solutions. Various properties of this new type of adsorbent with reference to the availability of heavy metals, its concentration, time factor for metal ion uptake, and sorbent concentration were also studied.

\section{Experimental}

2.1. Apparatus Used. X-ray diffraction (XRD) was performed using AXIOS PANalytical 2005. The analysis was made in the Central Metallurgical Research Institute in Alexandria, Egypt using the following: scanning electron microscope (SEM), atomic adsorption flame atomic absorption spectrophotometer (FAAS) (Model ICE) 3000, (Thermo Fischer-USA), spectrophotometer, and lab shaker.

\subsection{Adsorbents}

2.2.1. Natural Oil Shale. Egyptian oil shale was used in this work and was in the form of solid rock obtained from AlQuseir area (provided by the EMRA: Egyptian mineral resources authority). The oil shale was crushed and sieved, and particle size smaller than $150 \mu \mathrm{m}$ is used in the adsorption experiments. A portion without any treatment designated as (OS) is stored to be used in adsorption experiments, and the remaining amount is left for subsequent treatments.

2.2.2. Thermal Treatment. The thermal process is based on either calcination of OS in absence of air or burning it in air to produce ash. In the first method, oil shale (OS) was carbonized at $800^{\circ} \mathrm{C}$ for $1 \mathrm{~h}$ in absence of air, and product designated as (Carbo-OS) is obtained. To obtain oil shale ash (OS-ash), oil shale was burned using electrical furnace at $700^{\circ} \mathrm{C}$ for 2 hours to remove any organic matters. The two products (Carbo-OS and OS-ash) were washed with distilled water and dried in an oven at $110^{\circ} \mathrm{C}$ and then stored for adsorption experiments.

2.2.3. Chemical Treatment. In this case, oil shale (OS) was chemically activated using either mixture of $95 \mathrm{wt} . \%$ sulfuric acid and 5 wt.\% nitric acid, potassium hydroxide, and zinc chloride and finally using phosphoric acid. The methods of previous activation processes are as follows:

(1) Activation by $\mathrm{ZnCl}_{2}$. A known amount of oil shale (OS) was impregnated with $\mathrm{ZnCl}_{2}$ solution (30 wt.\%). The solid was then filtered and washed several times with hot water and then dried at $110^{\circ} \mathrm{C}$. The resulting sample was carbonized in absence of air for 1 hour at $600^{\circ} \mathrm{C}$. The carbonized product was washed with distilled water. After that, the material was redried at $110^{\circ} \mathrm{C}$ and designated with $\mathrm{ZnCl}_{2}$-OS.

The Egyptian oil shale used was obtained from Al Qusier area, which was in a solid state.

It was then crushed, followed by sieving, to separate the various particle sizes between $2.36 \mathrm{~mm}$ and 45 microns.

(2) Pyrolyzed Oil Shale. A reactor was placed in a furnace for external heating to carry out the pyrolysis of oil shale. Natural oil shale (size: 150 micron) was placed in this reactor. The oil shale was pyrolyzed at $750^{\circ} \mathrm{C}$ for 20 hours whereupon it was cooled and stored for further use.

2.3. Batch Adsorption Experiments. The synthesized adsorbents which have been discussed above, raw oil shale, pyrolyzed oil shale, and $\mathrm{ZnCl}_{2}$ were used to remove $\mathrm{Zn}^{2+}$ ions.

2.3.1. Procedure. A fixed amount of adsorbent, i.e., $0.2 \mathrm{~g}$ was added to bottles containing $50 \mathrm{ml} \mathrm{ZnSo}_{4} \cdot 7 \mathrm{H}_{2} \mathrm{O}\left(\mathrm{Zn}^{+2}\right)$ solution with different concentrations. Agitation was performed at $200 \mathrm{rpm}$ and constant temperature of $25^{\circ} \mathrm{C}$. Samples were taken at different times from 5 minutes to 60 minutes. The adsorbent was filtered from the rest of the sample. The filtrate was then analyzed for presence of any metal ions using atomic absorption spectrophotometer: calculating percent removed of the zinc ions by the three different adsorbents; raw, thermally activated, and chemically activated oil shale at variable contact times, initial concentration, and variable weights of adsorbent:

$$
\% R=\frac{C_{\mathrm{i}}-C_{\mathrm{f}}}{C_{\mathrm{i}}} .
$$

\section{Results and Discussion}

3.1. Characterization of the Adsorbent. The adsorbent used is crushed and screened oil shale; the adsorbent used in three different ways; first, it was as raw as it is, second, it was used when it was thermally activated at $750^{\circ} \mathrm{C}$ for 24 hours, and then finally when it was chemically activated by $\mathrm{ZnCl}_{2}$. Generally, the elemental composition of oil shale includes $\mathrm{C}-73.6 \%, \mathrm{H}-10.5 \%, \mathrm{~N}-0.7 \%$, and $\mathrm{O}+\mathrm{S}-15.2 \%$; atomic ratio $\mathrm{H} / \mathrm{C}-1.71$; degrees of aromaticity 0.19 , naphthenicity 0.53 , and alkyl substitution 0.28 [22, 23].

3.1.1. X-Ray Diffraction (XRD) Analysis of Adsorbent (Oil Shale). XRD analysis involves the study of the material that leads to confirmation of their crystalline structure. XRD analysis includes the study of type and relative position of atoms along with the length scale that marks the crystalline order. Hence, it can be used in measuring the crystalline structure through identification of its various phases and determining the presence of space between lattice planes and the length scales in addition to studying the preferential order and crystallite's epitaxial growth. After the $\mathrm{Zn}^{2+}$ 
adsorption, the intensity of diffraction peaks modifies a little, revealing that the adsorption of metal ions does not change the structure of adsorbent. The length scales are determined from sub $\AA$ to $\mathrm{nm}$ and seems to be highly sensitive in orders over tens of $\mathrm{nm}$ as shown in Figure 1.

Prominent structures of zeolite were determined by scanning electron microscopy (SEM). SEM involves excitation of the mounted sample material via electron beam that is focused on it. Once the beam hits the surface of the sample, it produces various signals, thus revealing the details about surface morphology of the sample with an approximate resolution of $1 \mathrm{~nm}$. SEM basically determines microstructure characteristics, and generally, the particles are distinguished by their spherical shape and smooth surface. In the present study, samples were evaluated under various conditions like high vacuum, low vacuum, wet conditions, and wide cryogenic or elevated range of temperatures as shown in Figure 2.

SEM also detects the secondary electrons generated by the atoms present in the sample that are collected by a detector for electron beams. SEM develops a topographic image of the sample's surface. In the present study, SEM gives details of the pore size in activated oil shale. Particle size is a highlighting factor to stimulate the removal efficiency. The obtained pore size data were compared to the pore sizes of raw oil shale, thermally and chemically activated oil shale, which showed increase in the size of the pore as well as adsorption capacity in case of thermally and chemically activated oil shale. In addition to this, pore size in thermally activated oil shale was seen to be wide in nature as compared to raw type, while the chemically activated type showed the widest pore size.

3.2. Adsorption of $\mathrm{Zn}^{+2}$ (by Three Adsorbents Prepared from Oil Shale). Zeolite-based removal of heavy metal cations is not a recent phenomenon. This particular has been studied extensively by many researchers in the literature. However, majority of the researchers have concluded it as an ion exchange among metal cations in the solution and those in the zeolite framework. Heavy metal ion removal is associated with various mechanisms of ion-exchange steps along with adsorption steps. At the ion-exchange procedure, metal ions move via the pores of zeolites and channels of lattice and restore exchangeable cations (dominated by sodium). The diffusion rate seems faster via pores and is delayed when the ions move via smaller channels. In the second situation, the metal ion adsorption may be associated with the ion-exchange reactions in the microporous minerals of the zeolite samples (oil shale).

3.2.1. Contact Time Effect on Percent Removal (by Three Adsorbents Prepared from Oil Shale). In general, the optimum $\mathrm{pH}$ at which $\mathrm{Zn}$ ions gets absorbed is 7 . In the present study, an increase in the percentage removal of $\mathrm{Zn}^{+2}$ up to 60 minutes was seen at $\mathrm{pH}=6.5-7$ (temperature $=25^{\circ} \mathrm{C}$; oil shale weight $=0.2 \mathrm{gm}$ ). Thus, the effective contact time for 60 minutes under the particular condition is $64.425 \%$, and it is independent of initial concentration (40 ppm), as shown in Figure 3.

With increasing contact time, the percentage removal of $\mathrm{Zn}$ increased in all the three adsorbents prepared from oil shale. The percentage removal of $\mathrm{Zn}$ was higher with the chemical activated oil shale (CA-OS) as compared to the other two oil shales. The percentage removal of $\mathrm{Zn}$ was lowest with the raw oil shale as compared to the other two oil shales (Figure 3 ). The percentage removal of $\mathrm{Zn}$ became almost steady beyond 30 minutes of contact time.

3.2.2. Effect of Initial Ion Concentration. Analysis in this test showed that the oil shale was a significant factor and was able to adsorb $\mathrm{Zn}^{2+}$ from their aqueous solutions. The results indicated that the concentration of $\mathrm{Zn}^{+2}$ was seen to increase from $20 \mathrm{ppm}$ to $100 \mathrm{ppm}$, with removal of $\mathrm{Zn}^{+2}$ adsorption from $25.66 \%$ to $92.7 \%$ (raw oil shale concentration $=20-100$; time $=60$ minutes; $\quad \mathrm{pH}=6.5 ; \quad$ temp $=25^{\circ} \mathrm{C} ; \quad$ oil shale weight $=0.2 \mathrm{gm})$.

The percentage removal of $\mathrm{Zn}$ decreased with increasing initial ion concentration in all the three types of adsorbents. At all the initial ion concentrations, the percentage removal of $\mathrm{Zn}$ was higher in the CA-OS as compared to the other types of adsorbents used and lowest for the raw oil shale (Figure 4), because chemical activation gives the adsorbent more active sites than thermal activation.

3.2.3. Effect of Adsorbent Weight. The adsorption of $\mathrm{Zn}^{+2}$ by raw oil shale at different dosages are $0.1 \mathrm{gm}$ to $0.5 \mathrm{gm}$. Initial concentration is $40 \mathrm{ppm}$, and the best dosage is $0.4 \mathrm{gm}$ of raw oil shale. The removal percentage was from 50.65 to 90.5 (raw oil shale $C_{\mathrm{i}}=40$, time $=60$ minutes, oil shale weight $=0.1-0.5 \mathrm{gm}, \mathrm{pH}=6.5$, temp $=25^{\circ} \mathrm{C}\left(\mathrm{Cu}^{+2}\right)$ ).

The percentage of $\mathrm{Zn}$ removal increased with increasing adsorbent weight with all the adsorbents. At all the adsorbent weights, the percentage removal of $\mathrm{Zn}$ was higher with CA-OS as compared to the other two adsorbents. The percentage removal of $\mathrm{Zn}$ was lowest for raw oil shale at all adsorbent weights (Figure 5).

3.3. Modeling of Adsorption Isotherm. An adsorbent's adsorption capacity can be theoretically calculated using an adsorption isotherm. The curve of the resulting isotherm is derived by a mathematical equation. Al-Qodah developed a two-resistance mass transfer model based on the film resistance and homogeneous solid phase diffusion. Moreover, the model concluded that the external mass transfer coefficient $\mathrm{K}$ was unaffected by difference in the initial dye concentration, but it improved when the agitation speed and temperature were increased [24].

However, in this study, the linear models of Langmuir (1918) and Freundlich (1926) were utilized to predict the result. The Langmuir constant (KL) and the Freundlich constant (Kf) are the indicators of sorption capacity.

3.3.1. Langmuir Isotherm. In the Langmuir model, it was supposed that the adsorbent has a limited adsorption 


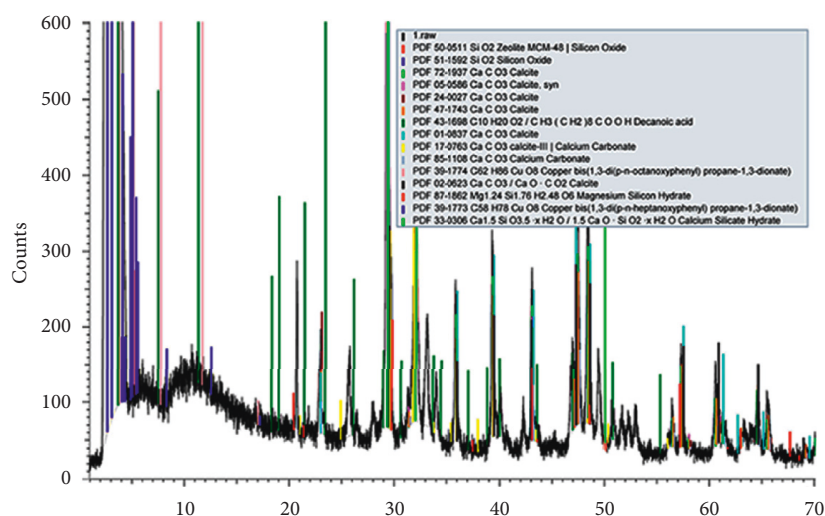

(a)

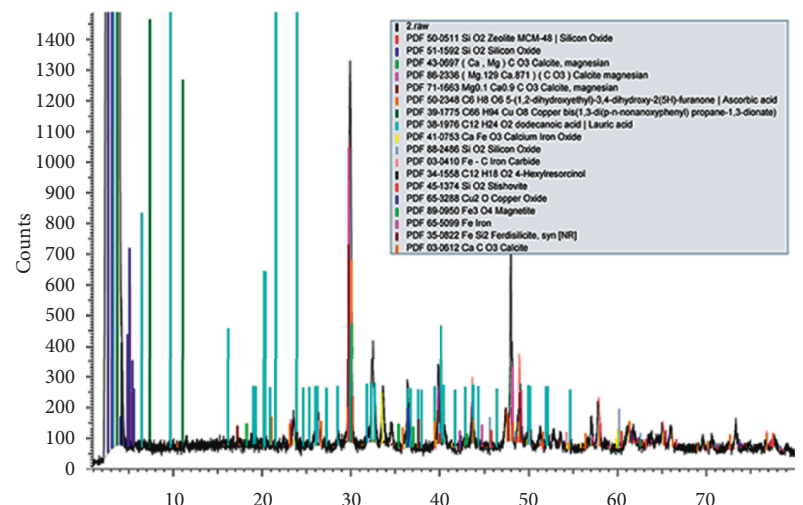

(b)

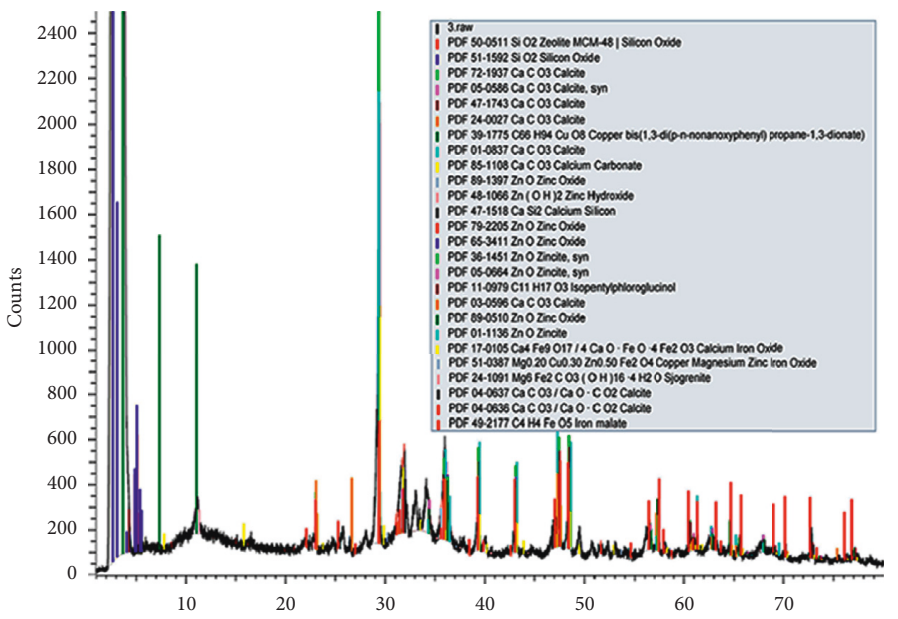

(c)

FIGURE 1: X-ray diffraction of (a) raw oil shale, (b) thermally activated oil shale, and (c) chemically activated oil shale.
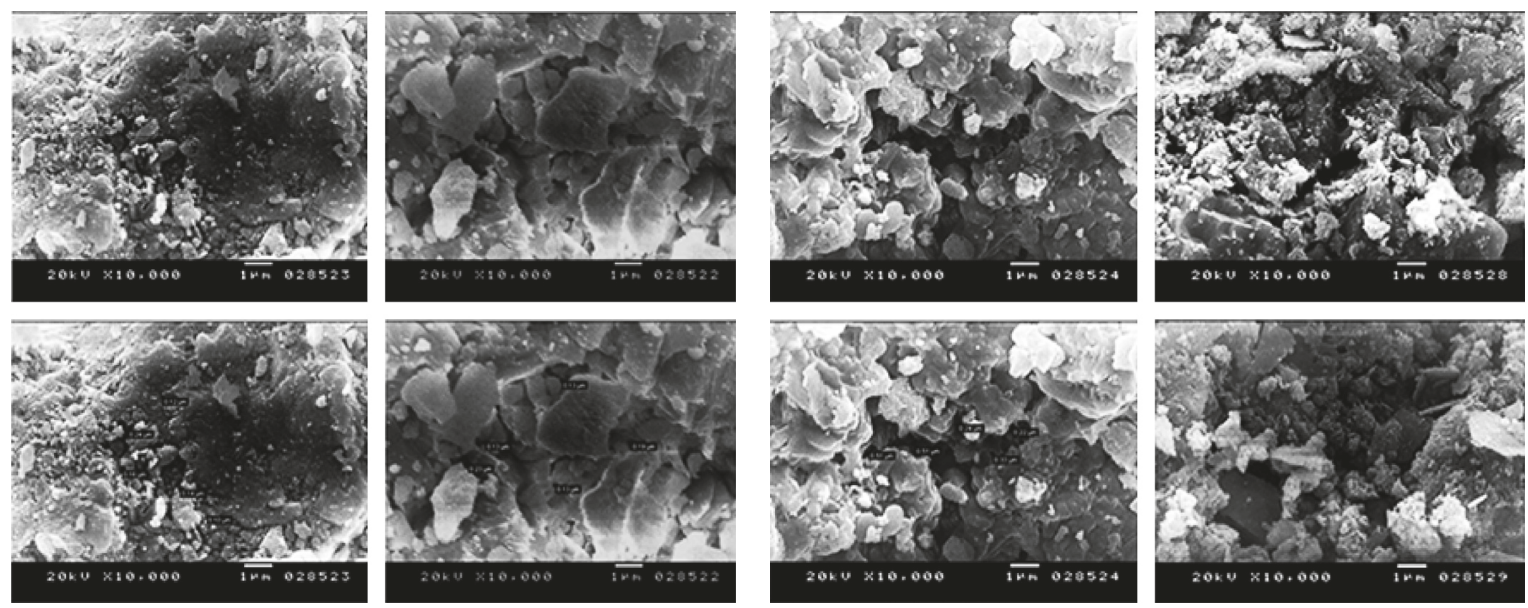

(a)

(b)

Figure 2: Continued. 

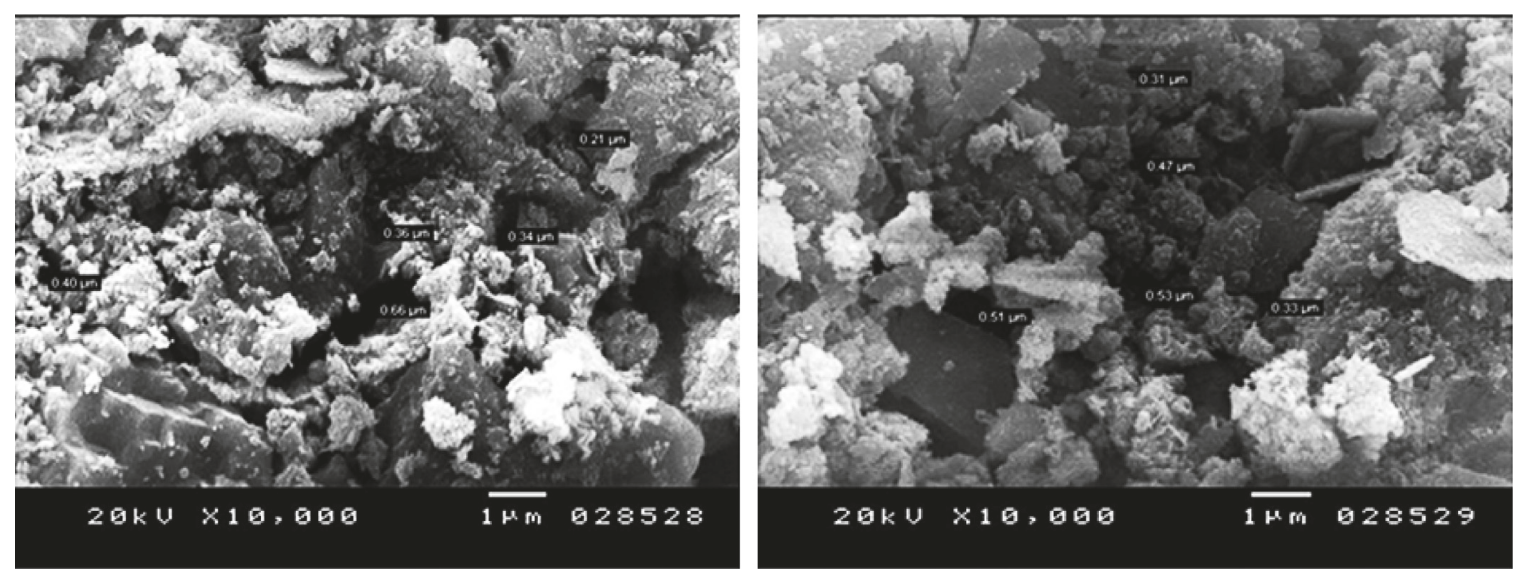

(c)

FIgURE 2: SEM of (a) raw oil shale, (b) thermally activated oil shale, and (c) chemically activated oil shale.

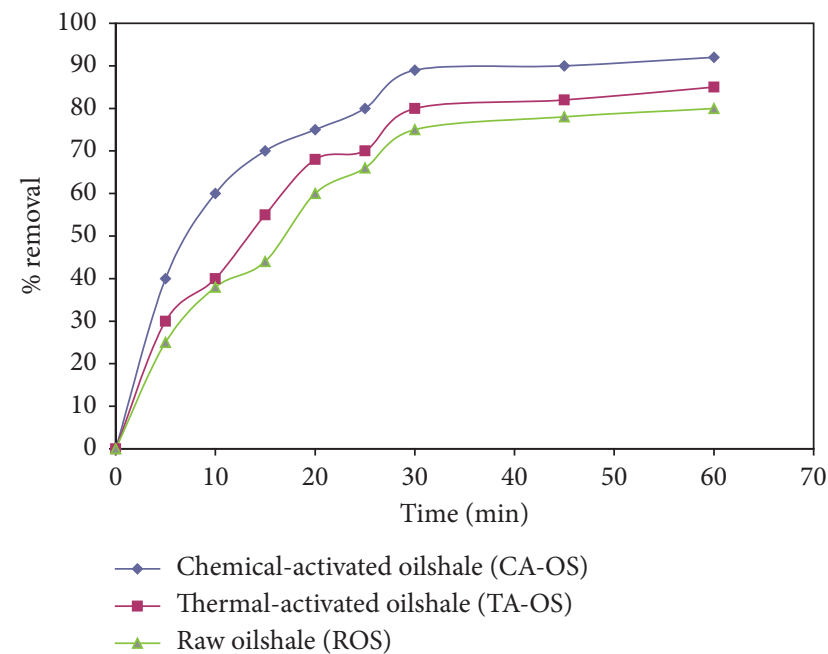

Figure 3: Comparing the effect of contact time on the percentage removal of $\mathrm{Zn}$.

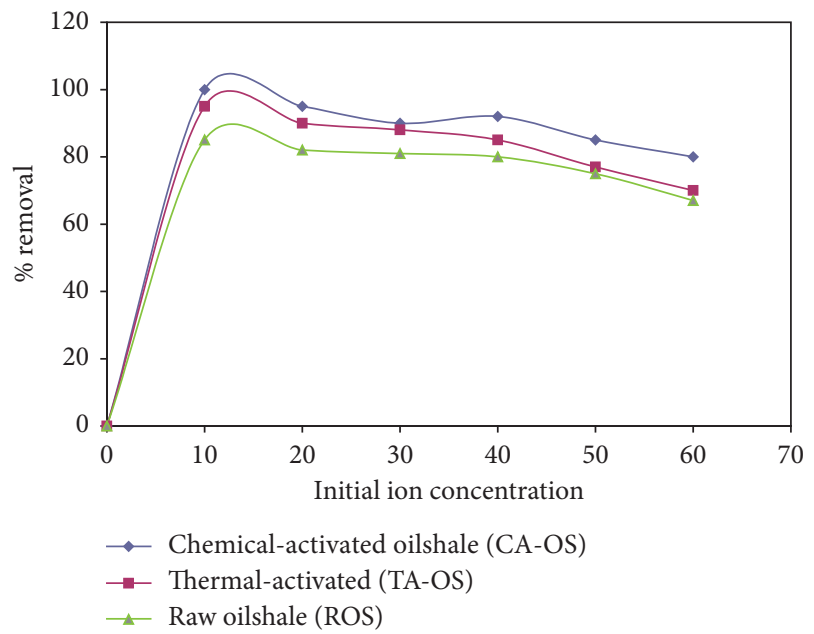

FIGURE 4: Comparing the effect of initial ion concentration on the percentage removal of $\mathrm{Zn}$.

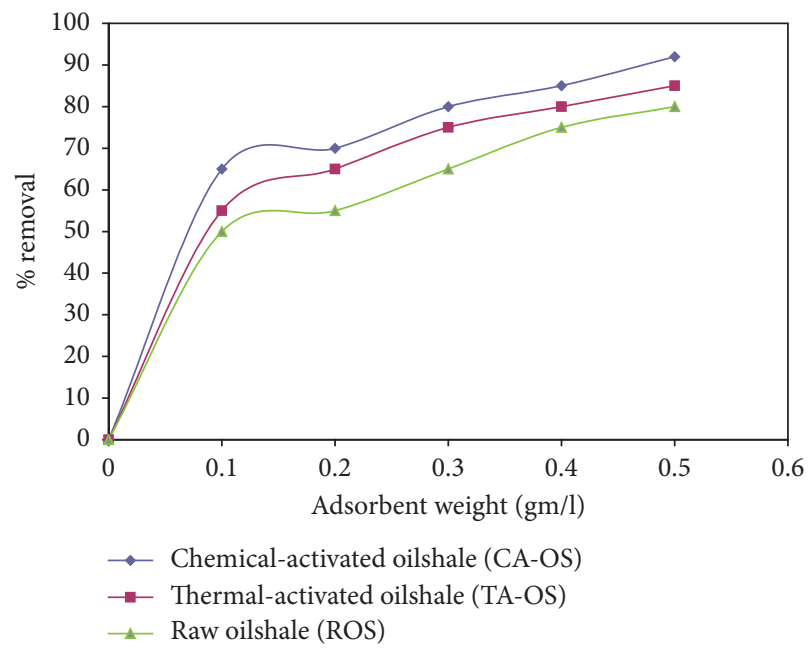

Figure 5: Comparison in the effect of adsorbent weight on the percentage removal of $\mathrm{Zn}$.

capacity, and all the active sites were identical, with each site complex only having one solute molecule alone (monolayer adsorption). Also, there were no interactions among the adsorbed molecules (Figure 6):

$$
\ln \frac{C_{\mathrm{e}}}{q_{\mathrm{e}}}=\frac{1}{Q_{0} \mathrm{KL}}+\frac{C_{\mathrm{e}}}{Q_{0}} .
$$

Plot of $C_{\mathrm{e}} / q_{\mathrm{e}}$ versus $C_{\mathrm{e}}$ gives straight line of slope $1 / Q_{0}$ and the intercept $1 / Q_{0} \mathrm{KL}$.

$q_{\mathrm{e}}$ is calculated by

$$
q_{\mathrm{e}}=\left(\frac{C_{\mathrm{i}}-C_{\mathrm{e}}}{m}\right)^{*} V
$$

where $Q_{\mathrm{e}}$ is the equilibrium amount adsorbed $(\mathrm{mg} / \mathrm{g}), C_{\mathrm{e}}$ is the equilibrium concentration of the adsorbate $(\mathrm{mg} / \mathrm{l}), \mathrm{m}$ is the mass of the adsorbent (gm), and $V$ is the volume of the solution (L). 


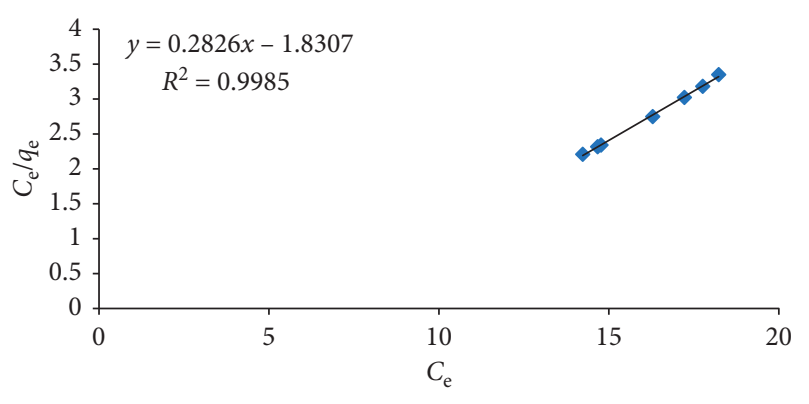

(a)

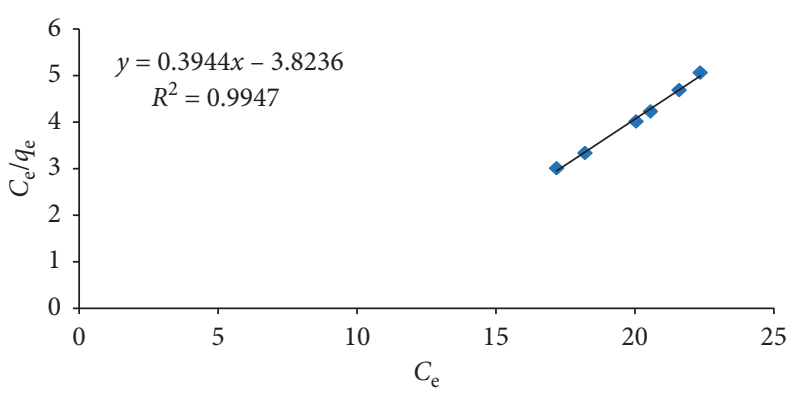

(b)

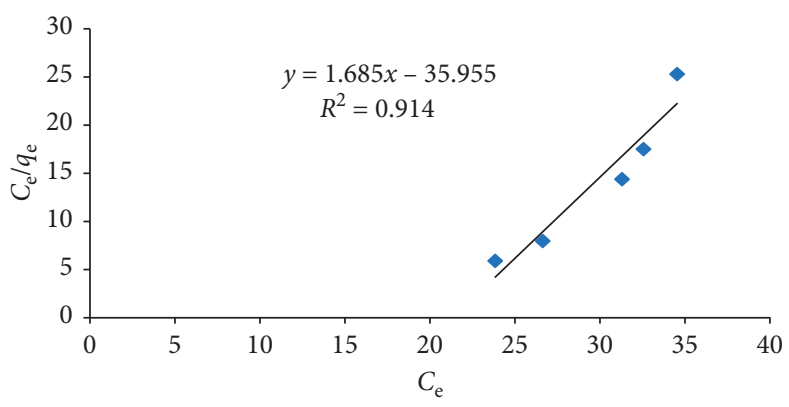

(c)

Figure 6: Langmuir isotherm for the adsorption process.

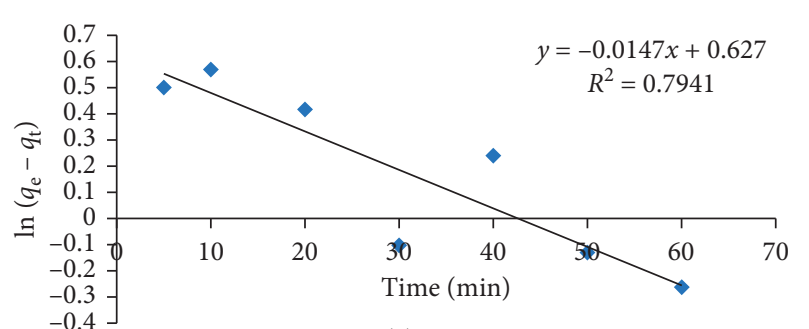

(a)

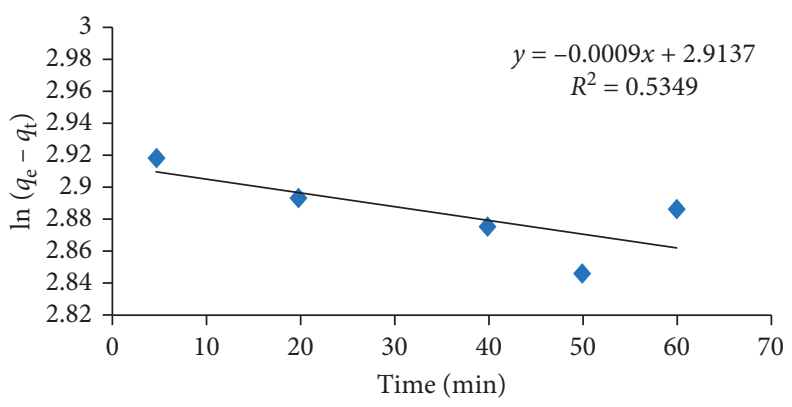

(b)

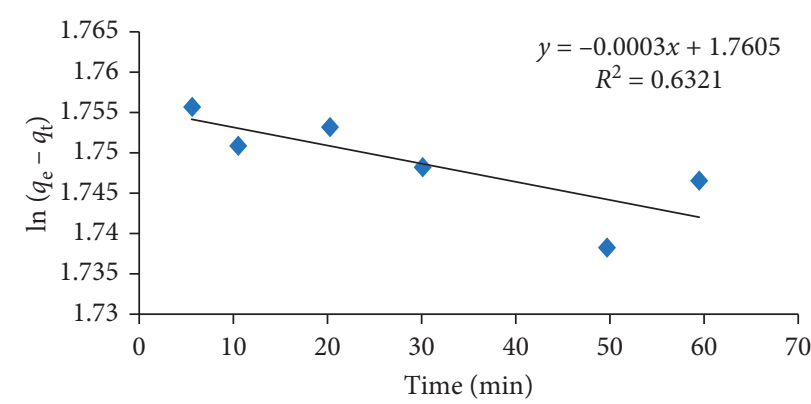

(c)

Figure 7: Pseudo-first order.

3.3.2. Freundlich Isotherm. Moreover, the Freundlich isotherm model (or empirical model) was applied to the adsorption at heterogeneous surfaces:

$$
\ln Q_{\mathrm{e}}=\ln \mathrm{Kf}+\frac{1}{n \ln C_{\mathrm{e}}} .
$$

Plot of $\ln \left(Q_{\mathrm{e}}\right)$ versus $\ln \left(C_{\mathrm{e}}\right)$ gives slope $1 / n$ and intercept $\mathrm{Kf}$, where $Q_{\mathrm{e}}$ is the equilibrium amount adsorbed $(\mathrm{mg} / \mathrm{g}), C_{\mathrm{e}}$ is the equilibrium concentration of the adsorbate $(\mathrm{mg} / \mathrm{l}), Q_{0}$ and $\mathrm{KL}$ are the Langmuir constants related to the adsorption capacity and energy of adsorption, respectively, and $\mathrm{Kf}$ and 


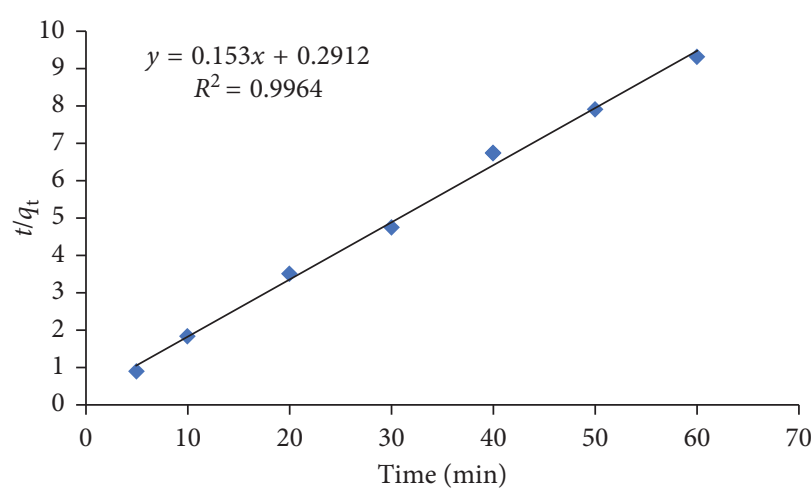

(a)

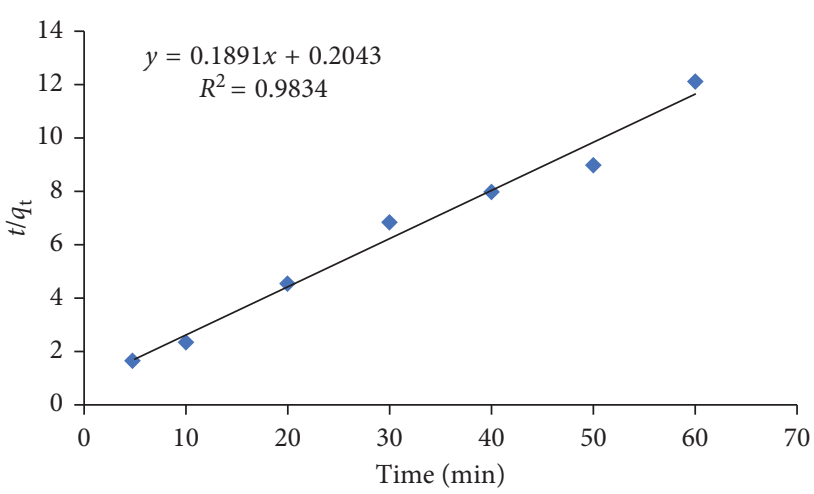

(b)

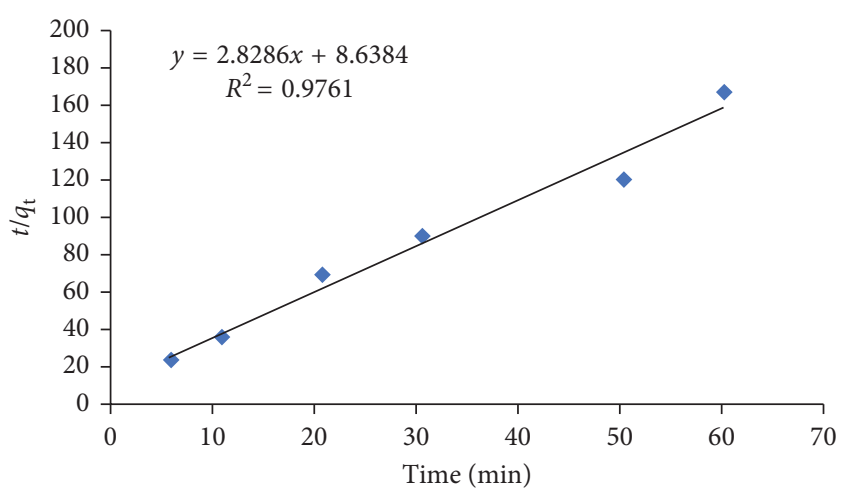

(c)

Figure 8: Pseudo-second order.

$1 / n$ are Freundlich constants related to adsorption capacity and intensity of adsorption.

3.4. Langmuir Isotherm Model for $\mathrm{Zn}^{+2}$. Calculation of Langmuir isotherm is also done by assumption; $C_{\mathrm{i}}$ is $40 \mathrm{ppm}$, and $C_{\mathrm{e}}$ is $C_{\mathrm{f}}$ at variable time from 5 minutes to 60 minutes, mass of adsorbent is $0.2 \mathrm{~g}$, and volume of solution is $50 \mathrm{ml}$ $\left(50 * 10^{-3} \mathrm{~L}\right)$.

3.5. Pseudo-First-Order Equation. To obtain the rate constant, the values of $\log \left(q_{\mathrm{e}}-q_{\mathrm{t}}\right)$ were linearly correlated with $t$ by plot of $\log \left(q_{\mathrm{e}}-q_{\mathrm{t}}\right)$ vs $t$ to give a linear relationship from $\mathrm{Kl}$ and predicated $q_{\mathrm{e}}$ that can be determined from the slope and intercept, respectively (Figure 7):

$$
\log \left(q_{\mathrm{e}}-q_{\mathrm{t}}\right)=\log q_{\mathrm{e}}-\left(\frac{K_{\mathrm{t}}}{2.303}\right) t
$$

3.6. Pseudo-Second-Order Equation. Plot of $t / q_{\mathrm{t}}$ vs. $t$ shows a linear relationship of $k$ and equilibrium adsorption capacity $q_{\mathrm{e}}$ which are evaluated from the intercept and slope:

$$
\frac{t}{q_{\mathrm{t}}}=\frac{1}{k 1 / q_{\mathrm{e}}^{2}}+\frac{1}{q_{\mathrm{e}} t} \text {. }
$$

The figure shows that adsorption of $\mathrm{Zn}$ on the various adsorbent types follows pseudo-second-order, because $R^{2}$ of second order is better than that of pseudo-first-order for both copper and zinc (Figure 8).

\section{Conclusions}

The morphological study of oil shale (SEM) indicates that the pores in chemical activation are higher than the pores in thermal activation and the raw oil shale. Oil shale can be used as an adsorbent of $\mathrm{Zn}^{2+}$ ions. Chemically activated oil shale with $\mathrm{ZnCl}_{2}$ needs to be considered as an effective adsorbent for $\mathrm{ZnSo}_{4}$ among the treated and tested oil shale. Increasing $\mathrm{Zn}^{2+}$ concentrations in the adsorbent suspension can result in an increase of its intake. Increased concentration of adsorbent results in an increase of $\mathrm{Zn}^{2+}$ removed from the solution.

\section{Data Availability}

The data used to support the findings of this study are included within the article.

\section{Conflicts of Interest}

All the authors declare that they have no conflicts of interest to declare.

\section{References}

[1] M. Jaishankar, T. Tseten, N. Anbalagan, B. B. Mathew, and K. N. Beeregowda, "Toxicity, mechanism and health effects of some heavy metals," Interdisciplinary Toxicology, vol. 7, no. 2, pp. 60-72, 2014. 
[2] X. Wu, S. J. Cobbina, G. Mao, H. Xu, Z. Zhang, and L. Yang, "A review of toxicity and mechanisms of individual and mixtures of heavy metals in the environment," Environmental Science and Pollution Research, vol. 23, no. 9, pp. 8244-8259, 2016.

[3] W. Yuan, N. Yang, and X. Li, "Advances in understanding how heavy metal pollution triggers gastric cancer," BioMed Research International, vol. 2016, Article ID 7825432, 10 pages, 2016.

[4] R. Singh, N. Gautam, A. Mishra, and R. Gupta, "Heavy metals and living systems: an overview," Indian Journal of Pharmacology, vol. 43, no. 3, pp. 246-253, 2011.

[5] K. Rehman, F. Fatima, I. Waheed, and M. S. H. Akash, "Prevalence of exposure of heavy metals and their impact on health consequences," Journal of Cellular Biochemistry, vol. 119, no. 1, pp. 157-184, 2018.

[6] T. Wajima, K. Murakami, T. Kato, and K. Sugawara, "Preparation of carbonaceous heavy metal adsorbent from coal using sulfur impregnation," Energy Sources, Part A: Recovery, Utilization, and Environmental Effects, vol. 32, no. 5, pp. 442-449, 2008.

[7] F. Lu, F. Zhao, J. Y. Cai, L. Liu, and X. M. Shi, "Progress in research of relationship between heavy metal exposure and cardiovascular disease," Chinese Journal of Epidemiology, vol. 39, pp. 102-106, 2018.

[8] R. A. Shawabkeh, "Adsorption of chromium ions from aqueous solution by using activated carbo-aluminosilicate material from oil shale," Journal of Colloid and Interface Science, vol. 299, no. 2, pp. 530-536, 2006.

[9] S. Al-Asheh, F. Banat, and A. Masad, "Kinetics and equilibrium sorption studies of 4-nitrophenol on pyrolyzed and activated oil shale residue," Environmental Geology, vol. 45, no. 8, pp. 1109-1117, 2004.

[10] S. Ichcho, E. Khouya, S. Fakhi et al., "Influence of the experimental conditions on porosity and structure of adsorbents elaborated from Moroccan oil shale of Timahdit by chemical activation," Journal of Hazardous Materials, vol. 118, pp. 45-51, 2005.

[11] E. Khouya, S. Fakhi, H. Hannache et al., "New adsorbents from oil shales: preparation, characterization and $U$, Th isotope adsorption tests," Journal of Radioanalytical and Nuclear Chemistry, vol. 260, no. 1, pp. 159-166, 2004.

[12] Z. Al-Qodah, M. A. Yahya, and M. Al-Shannag, "On the performance of bioadsorption processes for heavy metal ions removal by low-cost agricultural and natural by-products bioadsorbent: a review," Desalination and Water Treatment, vol. 85, pp. 339-357, 2017.

[13] Z. Al-Qodah, A. T. Shawaqfeh, and W. K. Lafi, "Adsorption of pesticides from aqueous solutions using oil shale ash," Desalination, vol. 208, no. 1-3, pp. 294-305, 2007.

[14] R. Shawabkeh, A. Al-Harahsheh, and A. Al-Otoom, "Copper and zinc sorption by treated oil shale ash," Separation and Purification Technology, vol. 40, no. 3, pp. 251-257, 2004.

[15] P. M. Pimentel, R. M. Oliveira, D. M. Melo, M. A. Melo, A. L. Assunção, and G. Gonzales, "Adsorption of chromium ions on oil shale waste," Brazilian Journal of Petroleum and Gas, vol. 5, no. 2, pp. 65-73, 2011.

[16] M. Shahid, B. Pourrut, C. Dumat, M. Nadeem, M. Aslam, and E. Pinelli, "Heavy-metal-induced reactive oxygen species: phytotoxicity and physicochemical changes in plants," Reviews of Environmental Contamination and Toxicology, vol. 232, pp. 1-44, 2014.

[17] H. S. Kim, Y. J. Kim, and Y. R. Seo, "An overview of carcinogenic heavy metal: molecular toxicity mechanism and prevention," Journal of Cancer Prevention, vol. 20, no. 4, pp. 232-240, 2015.

[18] N. L. Chávez-Gómez, A. Cabello-López, R. Gopar-Nieto et al., "Chronic kidney disease in Mexico and its relation with heavy metals," Revista médica del Instituto Mexicano del Seguro Social, vol. 55, no. 6, pp. 725-734, 2017.

[19] E. Chham, M. Khouya, A. Oumam et al., "The use of insoluble mater of Moroccan oil shale for removal of dyes from aqueous solution," Chemistry International, vol. 4, no. 1, pp. 67-77, 2018.

[20] E. Mitchell, S. Frisbie, and B. Sarkar, "Exposure to multiple metals from groundwater-a global crisis: geology, climate change, health effects, testing, and mitigation," Metallomics, vol. 3, no. 9, pp. 874-908, 2011.

[21] J. Astete, M. C. Gastañaga, and D. Pérez, "Levels of heavy metals in the environment and population exposure after five years of mineral exploration in the Las Bambas project, Peru 2010," Revista Peruana de Medicina Experimental y Salud Pública, vol. 31, no. 4, pp. 695-701, 2014.

[22] S. V. Rana, "Perspectives in endocrine toxicity of heavy metals--a review," Biological Trace Element Research, vol. 160, no. 1, pp. 1-14, 2014.

[23] P. X. Sheng, Y. P. Ting, J. P. Chen, and L. Hong, "Sorption of lead, copper, cadmium, zinc, and nickel by marine algal biomass: characterization of biosorptive capacity and investigation of mechanisms," Journal of Colloid and Interface Science, vol. 275, no. 1, pp. 31-141, 2004.

[24] Z. Al-Qodah, "Adsorption of dyes using shale oil ash," Water Research, vol. 34, no. 17, pp. 4295-4303, 2000. 

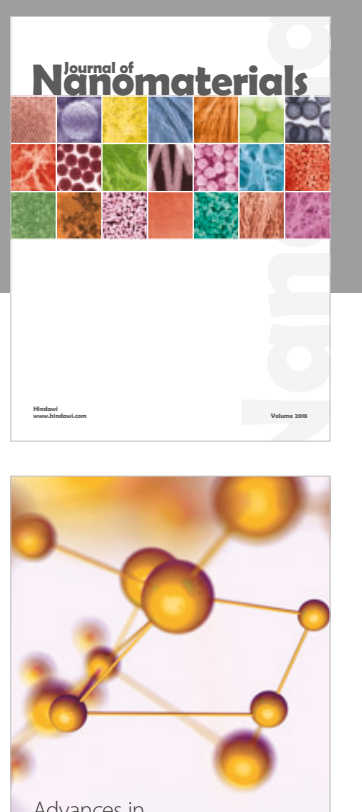

Physical Chemistry
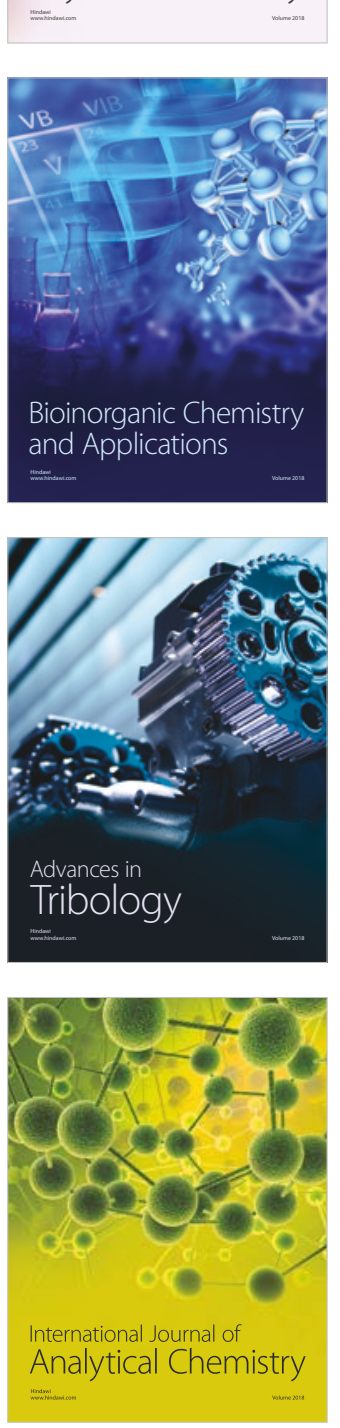

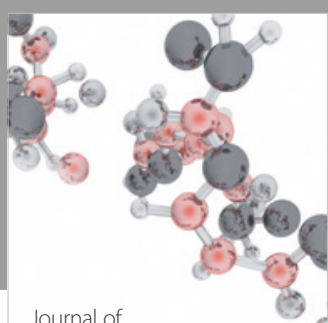

Analytical Methods

in Chemistry

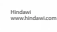

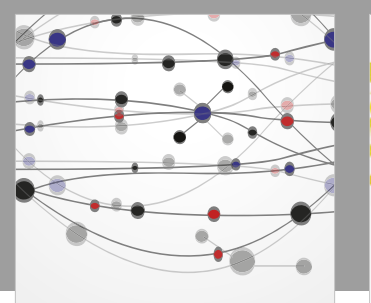

The Scientific World Journal

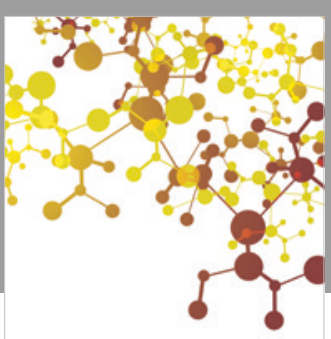

Journal of

Applied Chemistry
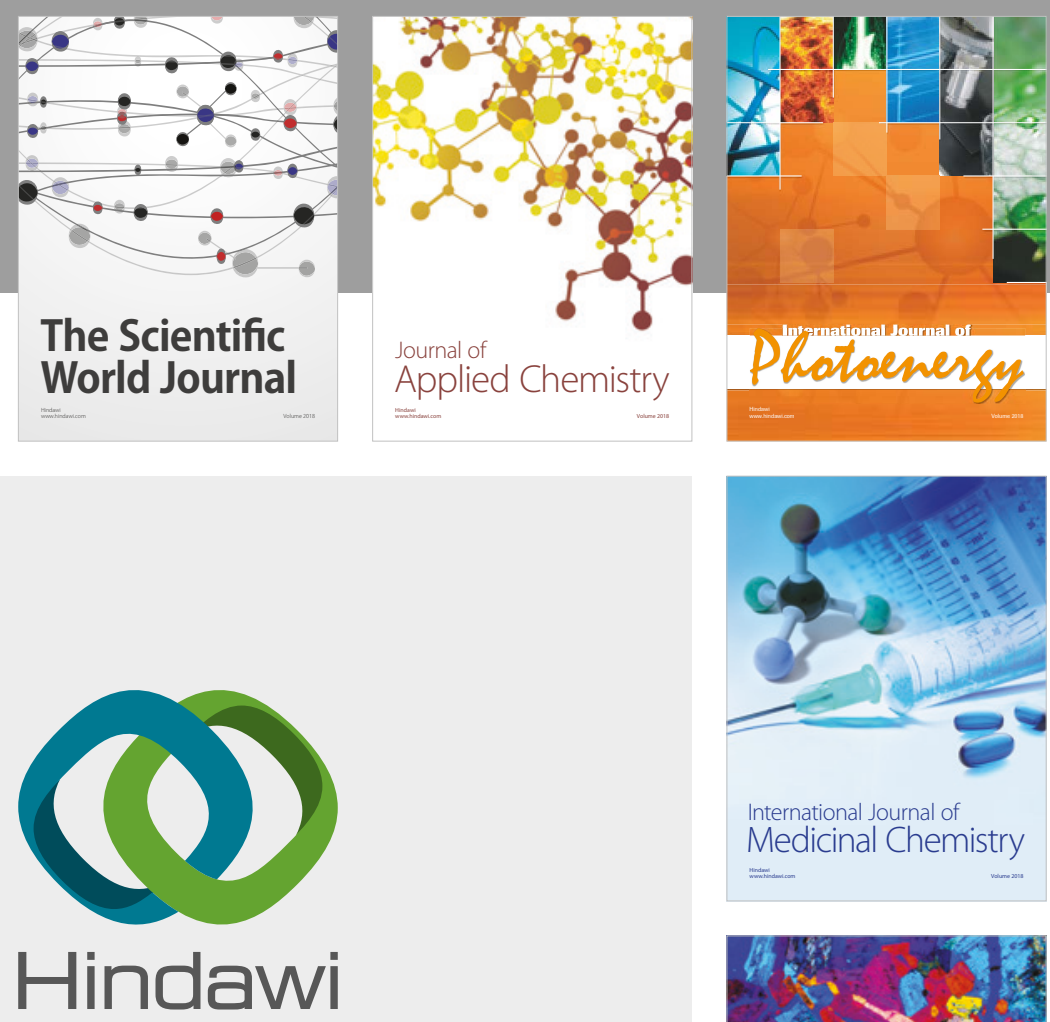

Submit your manuscripts at

www.hindawi.com
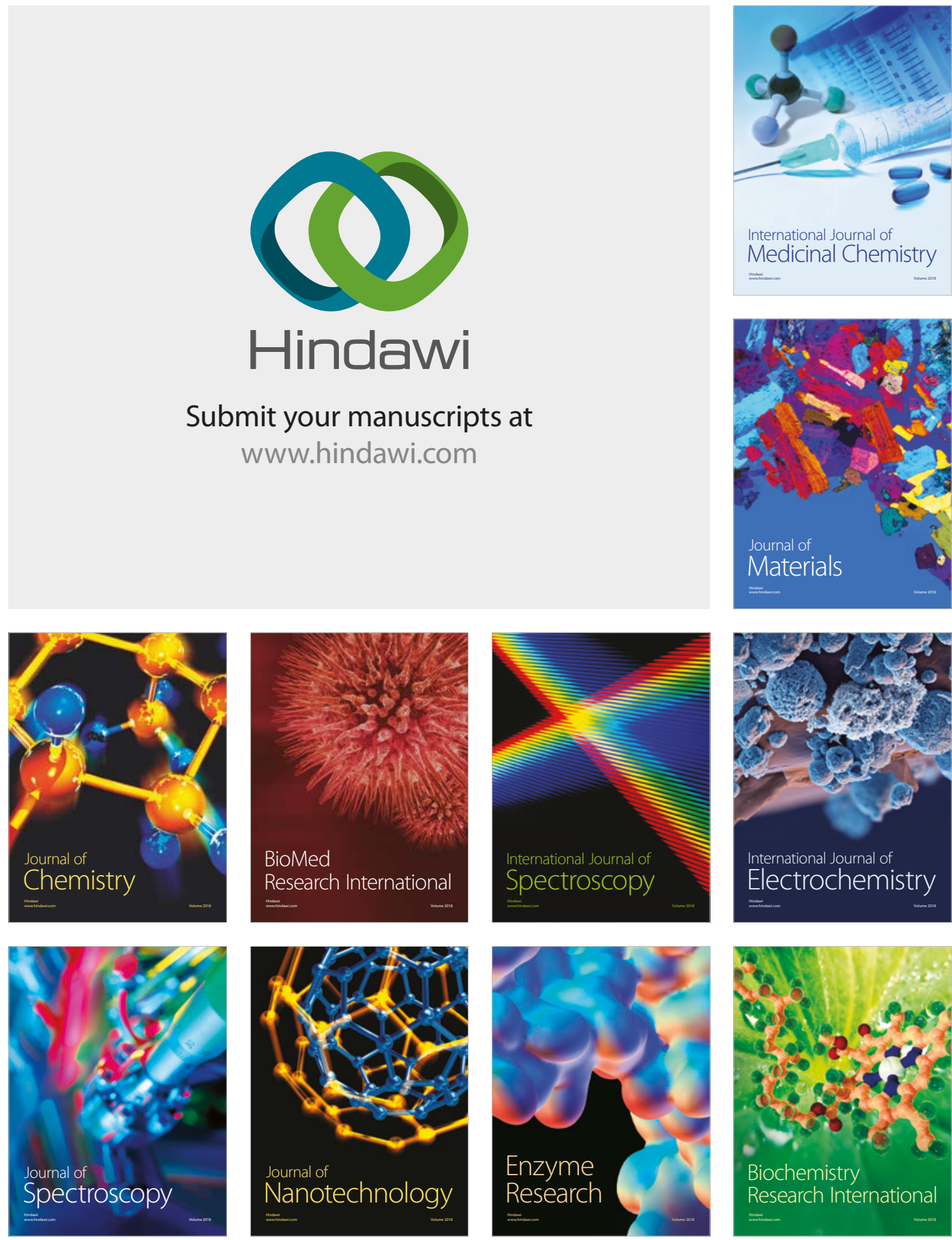
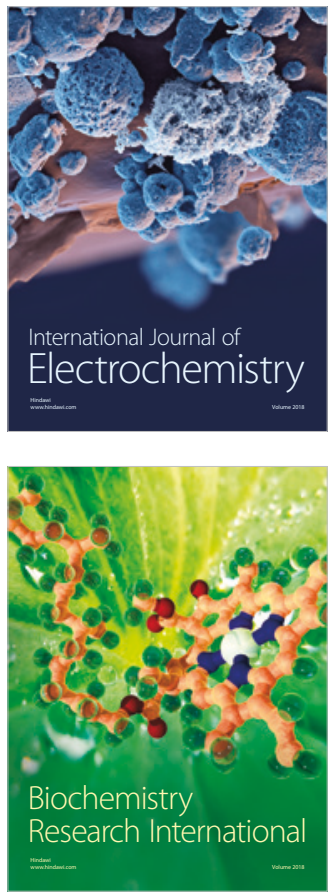